\title{
The Effectiveness of Interactive Video in the Achievement of Geography for Sixth Grades in Madaba Governorate Schools
}

\author{
Fatima Awad Al-Snaid", Manal A. Altawalbeh \\ Department of Special Education and Educational Technology, Faculty of Educational Sciences, Middle East University, Jordan
}

Received July 6, 2020; Revised August 10, 2020; Accepted September 11, 2020

\section{Cite This Paper in the following Citation Styles}

(a): [1] Fatima Awad Al-Snaid, Manal A. Altawalbeh, "The Effectiveness of Interactive Video in the Achievement of Geography for Sixth Grades in Madaba Governorate Schools," Universal Journal of Educational Research, Vol. 8, No. 10, pp. 4975 - 4979, 2020. DOI: 10.13189/ujer.2020.081070.

(b): Fatima Awad Al-Snaid, Manal A. Altawalbeh (2020). The Effectiveness of Interactive Video in the Achievement of Geography for Sixth Grades in Madaba Governorate Schools. Universal Journal of Educational Research, 8(10), 4975 4979. DOI: 10.13189/ujer.2020.081070.

Copyright $\subseteq 2020$ by authors, all rights reserved. Authors agree that this article remains permanently open access under the terms of the Creative Commons Attribution License 4.0 International License

\begin{abstract}
Effectiveness of an Interactive Educational Video on the Academic Achievement in Geography for Sixth-Grade Students in Madaba Governorate Schools. To achieve the objective of the study, the study was used as a quasi-experimental approach. The sample was chosen purposefully. The sample of the study consisted of (60) students of the sixth grade from the Ibntaimia School in Madaba Governate from the second semester in the university year 2019/2020. The study sample was distributed in an experimental group that has (30) students who were educated on the geography subject using an interactive video and the control group that has (30) students who were educated on the same geography subject using a traditional method. The achievement test (pre \& post-test) was prepared in one instrument, and the achievement test was distributed after testing the validity and reliability of the instrument, The results of this study presented that there were significant differences at the level of significant $(\alpha \leqslant 0.05)$ between the experimental and control group for the benefit of the experimental group in the post-test, which were studied using the interactive video. The study detected the effectiveness of the interactive video in increasing academic achievement in geography. According to the results, the researcher recommended using interactive video in schools because of its effective way of increasing academic achievement.
\end{abstract}

Keywords Effectiveness, Interactive Educational
Video, Educational Achievement, Geography

\section{Introduction}

The changes that took place at present and with the entry of the information era and the communication revolution called for the need to develop the programs of educational institutions to keep pace with those changes, and the interactive video is one of the most important modern technologies in the field of education and is considered a new model that contributes to the changes of the form of traditional education in such institutions [6].

The interactive educational video is one of the modern educational means in our contemporary world and its job lies in providing audio-visual information based on student's responses, which are reflected in his academic achievement, where the sound and image are presented through a screen that is part of a combined unit that includes a computer and a tool for entering information and storage fees, and therefore the interactive video capacity lies on providing information by using video clips and fixed frames along with text, sounds, graphics, and displays segmented video clips each on a separate screen. The display depends on a multi-screen system to show the different components of the lesson, thus the computer allows interaction opportunities for the student to have 
control according to his step, to the path and sequence and the amount of information he needs [11].

From here we see that the interactive video is an important development in educational technology as it contains unique features with several uses, including teaching, as it has technology that allows the learner to watch the video sequences and then questions are asked by the interactive educational video and includes the responses of the learner, and this, therefore, reflects positively on the achievement Study for the learner, as the researcher believes that activating the use of interactive video has become a necessity in teaching, especially the presence of a study that has proven effective in increasing academic achievement as a study [4].

Due to the importance of employing technology in education, learning, and teaching for students, it was necessary to enhance it's implementing to increase academic achievement in the subject of geography, to prepare students who can understand the subject of geography, therefore it was necessary to rely on the promotion of interactive video in this context and reduce the obstacles to its application, therefore the researcher generated interest and desire to reveal the effect of using the interactive video on the achievement of sixth graders in geography in Madaba Governorate by highlighting the interactive video in education and explaining its importance, goals, and effectiveness in increasing achievement in social education subjects in general and geography in particular, through the researcher's endeavor to develop an educational unit in teaching geography for sixth-grade students using the interactive educational video.

\subsection{Problem Statement}

The problem of the study stems from the work of an exploratory study on a number of teachers of geography and some of the students 'parents, who confirmed the existence of a decline in academic achievement in the subject of geography, and through the researcher's review of many previous studies that examine the effectiveness of the interactive video as a studies ([1], [2] , [3], [4], [5]) All of them have confirmed the existence of deficiencies in its use as an educational method in teaching some subjects, including geography, where teaching methods are still presented in the traditional way that relies on memorization and memorization, and that there is a dearth of using modern technical means, and the teacher relying on the textbook as a sole source of information seeking , Using only images that do not encourage the learner to fully understand the lessons, and given the importance of using interactive video in teaching geography and the paucity of studies on this subject in Jordan in general and the governorate of Madaba in particular. This study came to reveal the effectiveness of the interactive educational video in the academic achievement in geography for sixth-grade students in Madaba governorate schools.

\subsection{Study Aim}

This study aims to reveal the effectiveness of the interactive educational video in the academic achievement in geography for sixth-grade students in Madaba governorate schools.

\subsection{Study Hypothesis}

H01: There were no statistically significant differences at the level of significance $(\alpha \leq 0.05)$ between the mean scores of students of the experimental and control groups in the post-academic achievement test in geography in Madaba governorate attributed to the method of teaching (interactive video, the usual method).

\section{Literature Review}

[[10] showed a study aimed at identifying the effect of teaching mathematics using interactive video games and their influence on the achievement of fifth-grade students. This study was conducted in a private school in Jordan, the semi-experimental approach used by the researcher, the study sample consisted of experimental and the other Control. To know the differences between the experimental group and control groups, an interactive computer program was used and developed in which video games were used, and the two groups underwent two tests before and after. The results showed that the learning environment using interactive video games had a noticeable development in the performance of the experimental group that studied the content using the interactive video and this was reflected positively on the achievement of the experimental group in mathematics.

Also, [3] conducted a study aimed at investigating the impact of the use of interactive video on the achievement of tenth-grade students in Kuwait's history in Kuwait, the quasi-experimental approach used by the researcher. Sample study contained of (100) male and female students distributed among four of the tenth-grade people. Randomly (experimental group 48) were taught using the interactive video and the other (control group 52) students were taught in the usual way, and the measurement tool was (pre and post achievement), and the results showed that there were statistically significant differences in achievement among the study members due to the teaching method (Interactive video, the usual way) and for the benefit of students who have learned by using the interactive video.

Furthermore, [5] conducted a study aimed at measuring the effect of interactive video use in developing practical concepts in science for third-grade students in the average of Jeddah Governorate, where the semi-experimental curriculum was used and the study sample consisted of ((60 female students from the third-grade average student 
representing (30) One student is from the experimental group, while (30) students represent the control group. The achievement test was applied to the two groups before, then the experimental group was taught using the interactive video, while the control group in the traditional way, after which the post achievement test was applied, and the results indicated that there is a high impact of the use of the interactive video in developing the scientific concepts in the science subject to third-grade students are average at levels of recall, understanding application, and the three levels combined.

[8] also showed a study aimed at revealing the effectiveness of two types of inverted learning, namely regular video learning and interactive video learning in developing educational video design skills and production for students of Al-Aqsa University in Gaza, and the researcher used the semi-experimental approach and verified its effectiveness in developing video design skills. And its production with Al-Aqsa University female students, the research sample consisted of (50) female students, each of which the experimental group consisted of (25) female students, and the control group of (25) female students. The researcher used the achievement test tool and an evaluation card to measure the skills, and the results showed that the group of female students who studied using the interactive video outperformed.

As for the [2] study, which aimed to identify the effect of teaching using interactive video on educational achievement in the computer course for the first secondary school and to achieve the goal of the study, the quasi-experimental curriculum was used for a sample of first-year secondary students in Wadi Al-Dawasir Governorate in the Kingdom of Saudi Arabia, consisting of ( 48) A student, distributed into an experimental group, studied using interactive video, and the control group, studied using linear video, the researcher used the test as a study tool, and the results showed that there were no statistically significant differences between the two groups in the level of recall, while there were statistically significant differences in the level of understanding and application.

\section{Methodology}

\subsection{Study Approach}

A semi-experimental approach used by the researcher to outfit the purposes of the study [9] by creating two different groups: the experimental group that was educated using interactive video, and the control group that was educated in the usual way.

\subsection{Study Population and Sample}

The number of private schools that contain the sixth basic class of (38) schools has been limited according to the Ministry of Education statistics (2020/2020), and given the difficulty of conducting a study on each study community, one private school has been selected (Ibn Taymiyyah Comprehensive School) intentionally

\subsection{Study Tool}

To achieve the goals of the current study, which was to reveal the effectiveness of the interactive video program in the academic achievement of sixth-grade students in Madaba Governorate in Jordan, the researcher prepared the achievement test in geography, where the test included 20 multiple-choice questions.

\subsection{Study Validity and Reliability}

It was presented to a group of specialized arbitrators and faculty members in Jordanian universities to ensure the validity of the test. The reliability of the test instrument was verified by applying it to a sample outside the study sample, which consisted of (30) students. The reliability factor value was calculated by calculating the Cronbach alpha reliability factor, the Kuder-Richardson-20 reliability factor, and the return reliability factor. Table 1 shows the results of the analysis:

Table 1. The Cronbach alpha reliability factor and the repeatability coefficient

\begin{tabular}{|c|c|c|c|}
\hline \multicolumn{3}{|c|}{ Calculated reliability factor } & \multirow{2}{*}{$\begin{array}{c}\text { Coefficient o } \\
\text { honesty }\end{array}$} \\
\hline $\begin{array}{l}\text { Steady } \\
\text { return }\end{array}$ & $\begin{array}{c}\text { Coder-Richardson } \\
-20 \\
\end{array}$ & $\begin{array}{c}\text { Cronbach } \\
\text { Alpha }\end{array}$ & \\
\hline 0.949 & 0.970 & 0.969 & 0.964 \\
\hline
\end{tabular}

It is noted from Table 1 that all the values of the honesty coefficient were high, as well as the values of the coefficients of stability, and this enhances the validity, accuracy and appropriateness of the study instrument for achieving the purposes of the study.

\section{The Results}

to find out whether the difference in the mean of the female student's scores for the experimental and control groups in the post-application of the achievement test for geography is statistically significant at the level of significance $(\alpha \leq 0.05)$ and to isolate the difference between the two groups in the tribal application of the test, and accompanying variance analysis (ANCOVA) was used. Table 2 shows the results. 
Table 2. The results of the associated monoclinic analysis (ANCOVA) for the grades of grade sixth students for the control and experimental groups in the achievement test in the subject of geography according to the teaching method

\begin{tabular}{|c|c|c|c|c|c|c|c|}
\hline $\begin{array}{l}\text { Scale of } \\
\text { impact }\end{array}$ & $\begin{array}{c}\text { Eta squared value - } \\
\text { scientific } \\
\text { significance }\end{array}$ & $\begin{array}{c}\text { Significan } \\
\text { ce level }\end{array}$ & $\begin{array}{c}\text { Value (p) } \\
\text { Calculated }\end{array}$ & Average squares & $\begin{array}{c}\text { Degrees of } \\
\text { freedom }\end{array}$ & Sum of squares & $\begin{array}{c}\text { Source of } \\
\text { contrast }\end{array}$ \\
\hline & & & & 151.712 & 1 & 151.712 & Pre-test \\
\hline \multirow[t]{3}{*}{ Big } & .407 & .000 & 37.469 & 173.401 & 1 & 173.401 & $\begin{array}{c}\text { Teaching } \\
\text { method }\end{array}$ \\
\hline & & & & 4.628 & 57 & 263.788 & Error \\
\hline & & & & & 59 & 578.850 & Total \\
\hline
\end{tabular}

The results in Table 2 indicate that there is a statistically significant difference at the level of significance $(\alpha \leq 0.05)$ between the averages of female students' scores for the experimental group (which was subjected to the use of interactive educational video in teaching) and the control group (which was subject to the usual method), as it reached (P) Calculated (37.469) This value is statistically significant, which means rejecting the null hypothesis which states that "There are no statistically significant differences at the level of significance $(\alpha \leq 0.05)$ between the mean scores of students of the experimental and control groups in collecting geography in Madaba Governorate attributable to the use of the educational video Interactive in teaching ", meaning that there are an effect and effectiveness of using the interactive educational video in teaching geography for sixth graders.

To know the direction of the differences, the adjusted dimensional averages and standard errors for the degrees of the control and experimental groups in the post-test achievement in the subject of geography were calculated according to the teaching strategy, as in Table 3.

Table 3. Modified dimensional averages and standard errors for the scores of the members of the control and experimental groups in the achievement test in the subject of geography According to the teaching strategy

\begin{tabular}{|c|c|c|c|}
\hline $\begin{array}{c}\text { Standard } \\
\text { error }\end{array}$ & $\begin{array}{c}\text { Modified } \\
\text { dimensional } \\
\text { mean }\end{array}$ & number & The group \\
\hline 0.504 & 13.35 & 30 & Control \\
\hline 0.473 & 16.76 & 30 & Experimental \\
\hline
\end{tabular}

The results in Table 3 indicate that the adjusted dimensional mean for the control group members is (13.35) and that the adjusted dimensional mean for the members of the experimental group is (16.76), meaning that there is a statistically significant difference at the level of significance $(\alpha \leq 0.05)$ between the mean scores of the two groups Control and experimental achievement in geography for sixth-grade students attributed to the use of the interactive video in teaching and favor of the experimental group. And to find out the effect size of using the interactive educational video in the acquisition of geography, an ETA square ( $\eta 2$ ) whose value was (0.407) was calculated, meaning that $41 \%$ of the improved performance of female students in the experimental group in the post-test is attributable to the use of the interactive educational video according to the Cohen Standard i.e. The effect of using the interactive educational video on achievement in geography for sixth graders was significant.

\section{Discussion}

It is clear from the above that the learning strategy using the interactive educational video has succeeded in increasing the academic achievement of the experimental group, and this result may be due to several reasons, perhaps the most important of which is that learning using the interactive educational video is an effective way to motivate students to learn and positively impact what the video provides. The interactive learning is fun, joy and enthusiasm, and also, the learner uses more than one sense of learning and this helps in learning easily and preserving the information, and the learner can ask questions and this provides him with methods of self-evaluation, and the ability to follow the educational subject at different times, and thus attracts his interest through sound effects Photovoltaic and Kinetic.

The interactive video can link the video to the computer as it helps the learner in controlling the video presentation and controlling the footage and sound effects as well as in choosing colors and determining the duration and period of presentation, the learner learns through the interactive video faster, saves the information for a longer period, and develops the learner's abilities and skills that have a positive impact on his cognitive achievement.

The interactive educational video allows students to repeat, amend and review according to their desires and needs, which allows them to learn according to their capabilities and speed. It also helps the teacher to work more closely with students, and helps him reduce the need to repeat and repeat the explanation, in addition to that it attracts the learner's attention and excitement, And teachers also see that an interactive educational video helps students understand difficult concepts, promotes discussion among students and is also characterized by a speedy retrieval of information.

Interactive video is one of the important technologies in the field of education and it serves as a new model that contributes to changing the form of traditional education 
in educational institutions and also contributes to continuing education and training to train professionals in all areas of education. In light of this, interactive video programs are distinguished as having a high ability and high speed in providing training (education) appropriate for each student, according to his capabilities, needs, inclinations, or academic level.

This is consistent with the results of previous studies that showed that the experimental group achieved higher proportions using the interactive educational video that was used and that the interactive educational video has an impact, effectiveness and positive impact on students such as ([2], [3], and [4]).

\section{Recommendation}

In term of the study results, the researcher recommends the following:

1. Activating the use of the interactive educational video in teaching social subjects mainly because it has a positive effect in communicating information and increasing academic achievement in the primary classes.

2. Directing the attitudes of male and female teachers towards using the interactive video in teaching geography, specifically to increase the academic achievement of male and female students.

3. Carrying out more studies on other technologies and software that affect increasing the academic achievement of female and male students.

\section{Acknowledgments}

"The authors are grateful to the Middle East University, Amman, Jordan for the financial support granted to cover the publication fee of this research article".

\section{REFERENCES}

[1] Abdel Ghafour, Saeed (2015), The Effect of Using Some
Suggested Educational Media via the Global Network on the Academic Achievement of Ninth Graders in the Subject of Geography (unpublished master thesis) Khan Yunis Governorate.

[2] Al-Dosari, Saad bin Abdullah (2019). The Effect of Using Interactive Video in Teaching on Educational Attainment in the Computer Course for the First Year of Secondary School. International Journal of Educational Research. Volume 43, Issue 2.

[3] Al-Khalidi, Fahd Munshid (2017). The Effect of Using the Interactive Video on the Achievement of the Tenth Grade Students in the History of Kuwait in Kuwait. Master Thesis, Al-Bayt University, Mafraq.

[4] Al-Omari, Rania Attia (2014). The Effect of Using an Interactive Video on the Achievement of Science Subject for sixth-grade students in Baljurashi Governorate (Master Thesis), Al-Baha University.

[5] Al-Suraihi, Asma (2018). The Effect of Using Interactive Video on Developing Scientific Concepts in Science Subject for Third Grade Middle School Students in Jeddah Governorate. Journal of Educational and Psychological Sciences. The National Research Center in Gaza.

[6] Amer, Tariq Abdul Raouf (2015). E-Learning and Virtual Education Contemporary Global Trends, The Arab Group for Training and Publishing.

[7] Ammar, Haris, (2015). "Interactive Video technology and its Uses in Teaching and Learning Geography", Scientific Article, Nahr El-Alam Magazine.

[8] Harb, Solomon (2018). The Effectiveness of Inverted learning with Digital Video (normal / interactive) in Developing the Skills of Educational Video Design and Production for Students of Al-Aqsa University in Gaza. Palestinian Journal of Open and E-Learning, 6 (22), 65-78.

[9] Hoimmel, Ibtisam Nasser (2013). Experimental Approach (Pre-Ideal _ Semi-Experimental) Imam Muhammad bin Saud Islamic University: Riyadh.

[10] Ibrahim, B., \& Abo Hmaid, Y. (2017). The effect of teaching mathematics using interactive video games on the fifth grade students' Achievement. An- Najah University Journal for Research. (Humanities), 31(3), 471-492.

[11] Mazen, Hussam Muhammad (2009). Teaching and Learning Methods and Technology. Kafr El-Sheikh: Science and Faith for Publication and Distribution. 